DOI: https://doi.org/10.24843/JFU.2019.v08.i01.p06

pISSN: 2301-7716; eISSN: 2622-4607

Jurnal Farmasi Udayana, Vol 8, No 1, Tahun 2019, 36-43

\title{
Uji Aktivitas Analgesik Ekstrak Etanol Daun Jeruk Limau (Citrus amblycarpa (Haskk.) Ocshe) pada Mencit Jantan Galur Balb/C dengan Metode Hot Plate
}

\author{
Cahyaningsih, N.K. ${ }^{1}$, Satriawati, D.A. ${ }^{1}$, Wicaksana, I.G.P.A.P. ${ }^{1}$, Yulita, S. ${ }^{1}$, Sukarmini, N.N.F ${ }^{1}$, \\ Astuti, N.K.W.1, Yadnya-Putra, A.A.G.R ${ }^{1}$ \\ ${ }^{1}$ Program Studi Farmasi, Fakultas Matematika dan Ilmu Pengetahuan Alam, UNiversitas Udayana \\ Corresponden:kmgcabyani@gmail.com
}

\begin{abstract}
ABSTRAK
NSAID menjadi salah satu pilihan terapi untuk menghilangkan rasa nyeri.Namun, penggunaanya dalam jangka panjang dapat memicu efek samping yaitu pendarahan gastrointestinal. Oleh karena itu, diperlukan analgesik alternatif yang memiliki efek terapi yang sama dan efek samping yang lebih rendah. Salah satu tanaman yang memiliki potensi sebagai analgesik alternatif adalah Jeruk Limau (Citrus amblycarpa) yang dimanfaatkan sebagai obat kesemutan dan kram secara empiris. Penelitian ini dilakukan dengan tujuan untuk mengetahui aktivitas analgesik pada ekstrak etanol daun Citrus amblycarpa sebagai analgesik pada mencit putih jantan galur balb/c. Salah satu metode yang digunakan dalam pengujian aktivitas analgesik adalah metode Hot Plate. Penelitian dilakukan dengan membagi 30 ekor mencit ke dalam 6 kelompok kemudian masing-masing kelompok diberikan suspensi uji yang terdiri dari CMC-Na 1\% sebagai kontrol negatif, suspensi natrium diklofenak dosis 6,5 $\mathrm{mg} / \mathrm{kgBB}$ sebagai kontrol positif, dan suspensi ekstrak etanol daun $C$. amblycarpa dengan variasi dosis $100 \mathrm{mg} / \mathrm{kgBB}, 300 \mathrm{mg} / \mathrm{kgBB}$, dan $500 \mathrm{mg} / \mathrm{kgBB}$. Hewan uji ditempatkan di atas Hot Plate dengan suhu $70^{\circ} \mathrm{C}$ pada 30 menit setelah pemberian suspensi uji dan diamati waktu respon mencit terhadap panas setiap 30 menit selama 3 jam. Hasil uji kadar air serbuk simplisia daun C. amblycarpa adalah 4,492 \pm $0,0436 \%$ (b/b), persentase rendemen ekstrak metode maserasi adalah 21,403\% (b/b). Berdasarkan hasil uji aktivitas analgesik ekstrak etanol daun C. amblycarpa dapat disimpulkan bahwa pemberian ekstrak dosis 100, 300, dan $500 \mathrm{mg} / \mathrm{kgBB}$ memberikan aktivitas analgesik terhadap mencit dibandingkan dengan kontrol negatif (CMC-Na 1\%) dengan nilai ED50 sebesar 306,667 mg/kgBB.
\end{abstract}

Kata kunci: C. amblycarpa, Daun, Analgesik, Mencit Balb/c, Hot Plate

\section{ABSTRACT}

NSAIDs become one of the therapeutic options to relieve pain. However, if it is used for long term, the side effects such as gastrointestinal bleeding can be caused. Therefore, an alternative analgesic which has the same therapeutic effect and lower side effects are required. One of the plants that has a potential as an alternative analgesic is Lime (Citrus amblycarpa) which is used as an empirical medicine of tingling and cramps. This study aims to know the analgesic activity of the ethanol extract in Citrus amblycarpa leaves as an analgesic on white male mouse balb/c. One of the methods used in testing analgesic activity is the Hot Plate method. The study was conducted by dividing 30 mice into 6 groups and then each group was given a test suspension consisting of 1\% CMC-Na as negative control, diclofenac sodium suspension with a dose of $6,5 \mathrm{mg} / \mathrm{kgBW}$ as positive control, and suspension of ethanol extract of C. amblycarpa leaves with a dose of 100, 300 and $500 \mathrm{mg} / \mathrm{kgBW}$. The tested animals were placed on Hot Plate with a temperature of $70^{\circ} \mathrm{C}$ at 30 minutes after the suspension is given and the observation of mice's time response to heat was done every 30 minutes for 3 hours. The result of water content of $C$. amblycarpa leaves simplicia powder was 4,492 $\pm 0,0436 \%(w / w)$, the percentage of rendement of the extract with maceration method was 21,403\% (w/w). Based on the results of analgesic test, it can be concluded that giving extract with a dose of 100, 300, and $500 \mathrm{mg} / \mathrm{kgBW}$ presents analgesic activity in mice compared with the negative control (CMC-Na 1\%) and it'sED50 value was 306,667 mg / $\mathrm{kgBW}$.

Keywords: C. amblycarpa, Leaves, Analgesics, Balb/c Mice, Hot Plate 
DOI: https://doi.org/10.24843/JFU.2019.v08.i01.p06

pISSN: 2301-7716; eISSN: 2622-4607

Jurnal Farmasi Udayana, Vol 8, No 1, Tahun 2019, 36-43

\section{PENDAHULUAN}

Nyeri didefinisikan sebagai sensasi yang tidak nyaman dimana banyak penyakit yang dialami oleh masyarakat disertai oleh rasa nyeri. Rasa nyeri akan menyebabkan terbatasnya aktivitas yang dapat dilakukan oleh pasien dan berujung pada penurunan kualitas hidup. Oleh karena itu, perlu dilakukan upaya menghilangkan rasa nyeri pada pasien untuk meningkatkan kualitas hidup pasien dan mengembalikan kondisi pasien seperti semula (Kumar dan Svaha, 2011; WHO, 2012).

Terapi yang direkomendasikan untuk mengurangi rasa nyeri umumnya NSAID (Non Steroid Anti Inflammatory Drug) (WHO, 2012). NSAID umumnya dikombinasikan dengan obat-obatan golongan opioid untuk menghilangkan nyeri kronis (Lukman dan Harjanto, 2007), namun NSAID dapat memicu timbulnya efek samping yang tidak diinginkan apabila dikonsumsi dalam jangka panjang. Salah satu obat NSAID yang sering digunakan pada pasien osteoarthritis adalah natrium diklofenak yang dapat memicu efek samping pendarahan gastrointestinal apabila dikonsumsi dalam 1 tahun dengan dosis lazim yaitu 75 atau $100 \mathrm{mg}$ per hari (Miller et al., 2002).

Efek samping yang timbul dari penggunaan analgesik berkepanjangan menjadi dorongan bagi peneliti untuk mengembangkan analgesik alternatif dengan efektivitas lebih baik dan efek samping yang lebih rendah. Penelitian terhadap bahan alam telah banyak dilakukan untuk mengembangkan analgesik dengan aktivitas yang sama dengan efek samping yang lebih rendah.

Tanaman obat yang dapat dimanfaatkan untuk pengobatan analgesik adalah daun jeruk limau (Citrus amblycarpa (Hassk.) Osche). Belum ditemukan hasil penelitian terkait senyawa aktif yang terkandung dalam tanaman jeruk limau, namun secara umum kandungan senyawa pada daun jeruk terdiri atas flavonoid, saponin, dan steroid (Adrianto et al., 2014). Senyawa yang telah diketahui memiliki aktivitas analgesik adalah senyawa flavonoid yaitu hesperidin yang terkandung pada tanaman genus Citrus (Vabeiryureilai, et al., 2015).

Berdasarkan uraian diatas, maka peneliti ingin mengetahui aktivitas antipiretik ekstrak etanol daun jeruk limau (C. amblycarpa (Hassk.) Osche) terhadap mencit jantan galur balb/c (Mus musculus) dengan metode hot plate.

\section{BAHAN DAN METODE Bahan dan Alat}

Bahan yang digunakan dalam uji aktivitas analgesik adalah $\mathrm{CMC}-\mathrm{Na}$, akuades, dan natrium diklofenak. Peralatan yang digunakan adalah Oven (Binder( $\left.{ }^{\circledR}\right)$, blender, Hot Plate (Fisher Scientific), Vaccum Rotatory Evaporator (Eyela $\left.{ }^{\circledR}\right)$, Seperangkat alat-alat gelas (Pyrex $\left.{ }^{\circledR}\right)$, Sonde, timbangan analitik (AND®), toples, bak plastik, kotak kaca pengamat geliat, stopwatch, dan seperangkat komputer dengan software SPSS dan Ms. Office.

\section{Metode \\ Desain Penelitian}

Penelitian bersifat eksperimental murni dimana dilakukan perlakuan terhadap subjek uji dan bersifat eksploratif.

\section{Persiapan Bahan Uji}

Bahan yang digunakan dalam penelitian ini adalah daun jeruk limau (Citrus amblycarpa (Hassk.) Osche) yang diperoleh dari daerah Banjar Tegenungan, Desa Kemenuh, Kecamatan Sukawati. Determinasi tanaman dilakukan di Balai Konservasi Tumbuhan Kebun Raya 'Eka Karya' - Lembaga Ilmu Pengetahuan Indonesia (LIPI), Candikuning, Tabanan, Bali. Daun dibersihkan dengan air bersih kemudian diangin-anginkan dan dihaluskan hingga diperoleh serbuk kering. Serbuk kering daun jeruk limau sebanyak $500 \mathrm{~g}$ dimaserasi dengan etanol $70 \%$, kemudian disaring. Maserat yang diperoleh diuapkan dengan vacuum rotary evaporator di Laboratorium Fitokimia, Program Studi Farmasi, Fakultas 
DOI: https://doi.org/10.24843/JFU.2019.v08.i01.p06

pISSN: 2301-7716; eISSN: 2622-4607

Jurnal Farmasi Udayana, Vol 8, No 1, Tahun 2019, 36-43

Matematika dan Ilmu Pengetahuan Alam, Universitas Udayana.

\section{Pengujian Aktivitas Analgetik}

Pengujian aktivitas analgesik ekstrak etanol daun jeruk limau (Citrus amblycarpa) dilakukan terhadap 30 ekor mencit jantan galur $\mathrm{Balb} / \mathrm{c}$ dengan kriteria berumur 35-60 hari, berat badan 18-35 gr, sehat dan tidak stress (aktivitas normal) yang dibagi menjadi enam kelompok perlakuan. Sebelum perlakuan, hewan uji diaklimatisasi selama 7 hari dan puasa selama 18 jam (diberi minum ad libitum). Pada hari pengujian, masing-masing hewan uji diberikan perlakuan sesuai dengan kelompoknya. Berikut merupakan tabel perlakuan hewan uji tiap kelompok:

Tabel 1. Perlakuan kelompok uji

\begin{tabular}{cl}
$\begin{array}{c}\text { Kelompok } \\
\text { Uji }\end{array}$ & \multicolumn{1}{c}{ Perlakuan } \\
\hline 1 & $\begin{array}{l}\text { Suspensi CMC-Na } 1 \% \mathrm{~b} / \mathrm{v} \text { secara } \\
\text { peroral tanpa diinduksi nyeri } \\
\text { (Kelompok normal) }\end{array}$ \\
\hline 2 & $\begin{array}{l}\text { Suspensi CMC-Na } 1 \% \mathrm{~b} / \mathrm{v} \text { secara } \\
\text { peroral (Kontrol negatif) }\end{array}$ \\
\hline 3 & $\begin{array}{l}\text { Suspensi Na-Diklofenak secara } \\
\text { peroral (Kontrol positif) }\end{array}$ \\
\hline 4 & $\begin{array}{l}\text { Suspensi ekstrak etanol daun } C . \\
\text { amblycarpa } 100 \mathrm{mg} / \mathrm{kgBB} \text { (Dosis I) }\end{array}$ \\
\hline 5 & $\begin{array}{l}\text { Suspensi ekstrak etanol daun } C . \\
\text { amblycarpa } 300 \mathrm{mg} / \mathrm{kgBB} \text { (Dosis II) }\end{array}$ \\
\hline 6 & $\begin{array}{l}\text { Suspensi ekstrak etanol daun } C . \\
\text { amblycarpa } 500 \mathrm{mg} / \mathrm{kgBB} \text { (Dosis } \\
\text { III) }\end{array}$ \\
\hline
\end{tabular}

Setelah 30 menit diberi perlakuan, hewan uji kecuali kelompok 1 ditempatkan di atas Hot Plate dengan suhu $70^{\circ} \mathrm{C}$. Waktu yang terlewat antara penempatan hewan di piring panas dan adanya perilaku menjilati telapak kaki, gemetar, atau melompat dari permukaan dicatat sebagai respon latensi dalam hitungan detik. Kemudian diukur waktu reaksi dari perilaku pertama yang ditimbulkan dimana respon yang diamati adalah menjilati telapak kaki. Pengukuran dilakukan setiap 30 menit selama 180 menit dengan waktu cut-off untuk latensi plat panas ditetapkan pada 15 detik (Sivananda et al., 2013).

Selanjutnya dilakukan perhitungan aktivitas analgesik menggunakan rumus berikut:

$$
\% \text { Aktivitas Analgesik }=\frac{T-K}{\mathrm{C}-\mathrm{K}} \times 100
$$

Keterangan:

$\mathrm{T}=$ waktu respon setelah diberi suspensi ekstrak etanol daun C. amblycarpa

$\mathrm{K}$ = waktu respon kelompok kontrol negatif

$\mathrm{C}=$ waktu cut-off (15 detik)

\section{HASIL Ekstraksi}

Maserasi daun C. amblycarpa dilakukan dengan pelarut etanol $70 \%$ dan dilakukan remaserasi sebanyak 2 kali. Pemilihan pelarut etanol juga didasarkan pada monografi Farmakope Herbal Indonesia yang menyatakan bahwa apabila tidak dinyatakan lain, pelarut yang digunakan dalam ekstraksi adalah etanol (Depkes RI, 2008). Serbuk daun C. amblycarpa yang digunakan sebanyak 500 gram dengan bobot rendemen 107,015 gram $(21,403 \mathrm{~b} / \mathrm{b})$.

\section{Uji aktivitas analgesik}

Hasil uji aktivitas analgesic dapat dilihat pada tabel 2. dan gambar 1.

\section{PEMBAHASAN}

Penelitian ini menggunakan sampel berupa daun tua $C$. amblycarpa dengan warna hijau tua, lebar daun 4-7,5 $\mathrm{cm}$ dan panjang daun 7-9 $\mathrm{cm}$. Pengambilan sampel daun $C$. amblycarpa dilakukan dari tanaman yang sama dan pada waktu yang relatif sama karena variasi pengambilan sampel tanaman dapat mempengaruhi kandungan senyawa kimia pada tanaman yang diakibatkan oleh perbedaan kondisi lingkungan hidup tanaman yang meliputi air, suhu, curah hujan, kelembaban, cahaya, dan unsur hara yang terkandung pada tanah (Chaidir et al., 2016).

Ekstraksi daun $C$. amblycarpa dilakukan dengan metode maserasi dengan pelarut etanol 
DOI: https://doi.org/10.24843/JFU.2019.v08.i01.p06

pISSN: 2301-7716; eISSN: 2622-4607

Jurnal Farmasi Udayana, Vol 8, No 1, Tahun 2019, 36-43

$70 \%$ untuk mencegah penurunan mutu ekstrak yang diakibatkan oleh hilangnya senyawa

Tabel 2. Tabel Hasil Uji Aktivitas Analgesik

\begin{tabular}{|c|c|c|c|c|c|c|c|}
\hline \multirow{2}{*}{\multicolumn{2}{|c|}{ Perlakuan }} & \multicolumn{6}{|c|}{ Respon Mencit Terhadap panas (Detik) } \\
\hline & & 30 menit & 60 menit & 90 menit & 120 menit & 150 menit & 180 menit \\
\hline \multirow{5}{*}{$\begin{array}{c}\text { Kelompok } 1 \\
\text { (Normal) }\end{array}$} & I & 1 & 2 & 2 & 2 & 3 & 2 \\
\hline & II & 1 & 1 & 2 & 2 & 2 & 4 \\
\hline & III & 2 & 2 & 4 & 1 & 2 & 2 \\
\hline & IV & 3 & 1 & 2 & 2 & 4 & 3 \\
\hline & $\mathrm{V}$ & 3 & 3 & 1 & 3 & 3 & 2 \\
\hline \multirow{5}{*}{$\begin{array}{c}\text { Kelompok } 2 \\
\text { (Kontrol } \\
\text { Negatif) }\end{array}$} & $\mathrm{I}$ & 2 & 1 & 1 & 2 & 2 & 2 \\
\hline & II & 1 & 2 & 2 & 3 & 2 & 3 \\
\hline & III & 2 & 2 & 4 & 1 & 4 & 3 \\
\hline & IV & 2 & 2 & 3 & 2 & 3 & 2 \\
\hline & $\mathrm{V}$ & 3 & 3 & 2 & 3 & 3 & 3 \\
\hline \multirow{5}{*}{$\begin{array}{c}\text { Kelompok } 3 \\
\text { (Kontrol } \\
\text { positif) }\end{array}$} & I & 7 & 9 & 10 & 13 & 11 & 10 \\
\hline & II & 5 & 8 & 13 & 14 & 12 & 10 \\
\hline & III & 7 & 10 & 13 & 14 & 13 & 11 \\
\hline & IV & 8 & 8 & 12 & 13 & 11 & 8 \\
\hline & $\mathrm{V}$ & 6 & 10 & 11 & 12 & 10 & 9 \\
\hline \multirow{5}{*}{$\begin{array}{c}\text { Kelompok } 4 \\
\text { (Dosis I) }\end{array}$} & I & 3 & 3 & 4 & 6 & 6 & 5 \\
\hline & II & 3 & 4 & 4 & 6 & 5 & 5 \\
\hline & III & 4 & 5 & 7 & 6 & 7 & 5 \\
\hline & IV & 3 & 4 & 5 & 7 & 6 & 4 \\
\hline & $\mathrm{V}$ & 4 & 5 & 5 & 6 & 5 & 4 \\
\hline \multirow{5}{*}{$\begin{array}{c}\text { Kelompok } 5 \\
\text { (Dosis II) }\end{array}$} & I & 4 & 6 & 7 & 8 & 6 & 3 \\
\hline & II & 3 & 4 & 7 & 9 & 8 & 8 \\
\hline & III & 4 & 6 & 8 & 7 & 8 & 6 \\
\hline & IV & 6 & 7 & 10 & 8 & 7 & 5 \\
\hline & $\mathrm{V}$ & 4 & 6 & 7 & 9 & 7 & 5 \\
\hline \multirow{5}{*}{$\begin{array}{l}\text { Kelompok } 6 \\
\text { (Dosis III) }\end{array}$} & I & 5 & 6 & 9 & 13 & 10 & 8 \\
\hline & II & 6 & 10 & 11 & 14 & 9 & 8 \\
\hline & III & 5 & 7 & 10 & 12 & 12 & 9 \\
\hline & IV & 6 & 7 & 9 & 11 & 10 & 7 \\
\hline & $\mathrm{V}$ & 6 & 8 & 8 & 11 & 9 & 7 \\
\hline
\end{tabular}

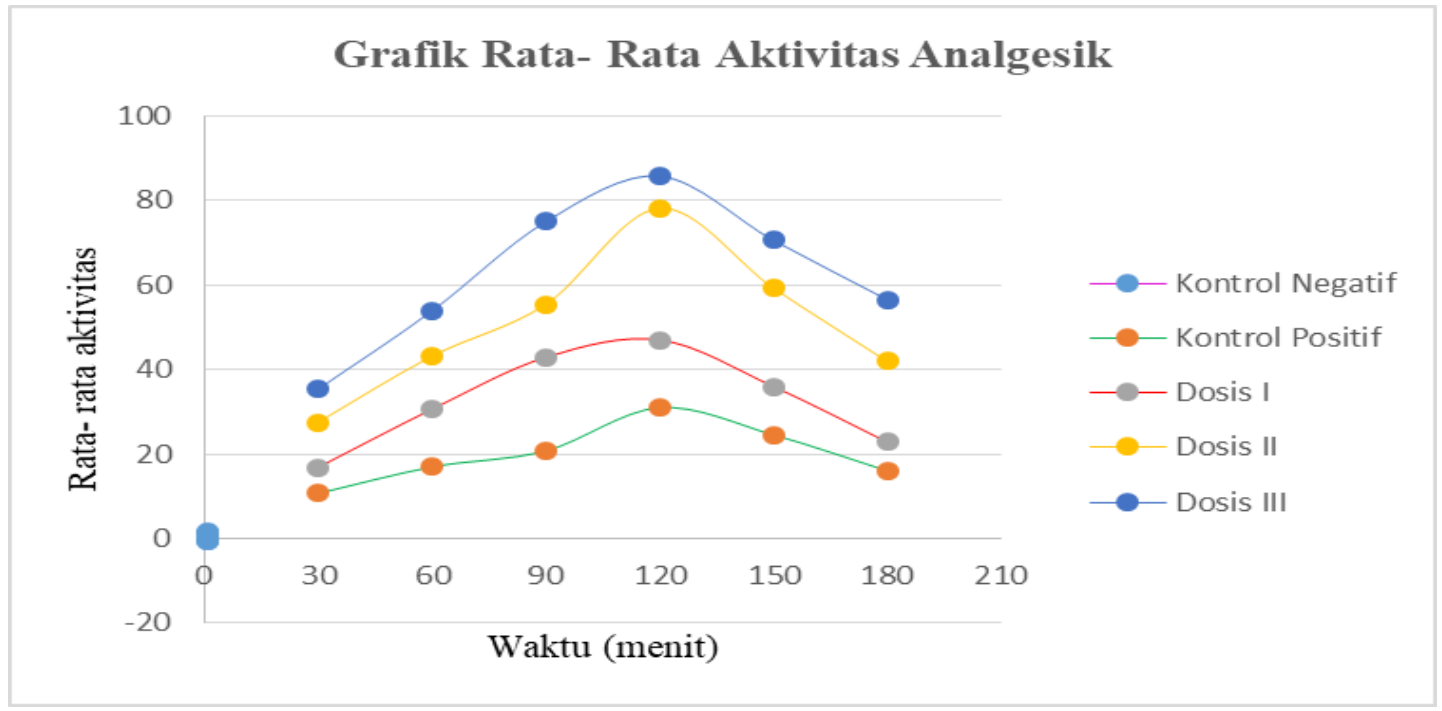


DOI: https://doi.org/10.24843/JFU.2019.v08.i01.p06

pISSN: 2301-7716; eISSN: 2622-4607

Jurnal Farmasi Udayana, Vol 8, No 1, Tahun 2019, 36-43

Gambar 1. Grafik Rata-Rata Aktivitas Analgesik

minyak atsiri yang mudah menguap apabila didiamkan diruang terbuka dan dipanaskan pada suhu tinggi (Sampoerno et al., 2000).

Pengujian aktivitas analgesik pada penelitian ini dilakukan secara in-vivo, subjek penelitian yang digunakan berupa makhluk hidup utuh. Hewan uji yang digunakan sebagai sampel penelitian adalah 30 ekor mencit putih jantan galur balb/c yang berusia 4 minggu. Mencit putih jantan galur balb/c dipilih sebagai hewan uji dikarenakan memiliki kesamaan fisiologis dengan manusia serta kemudahan dalam pemeliharaan dan perlakuan (Arrington, 1972). Pemilihan mencit jantan sebagai subjek penelitian dikarenakan memiliki kondisi hormonal yang lebih stabil daripada mencit betina sehingga dapat mencegah biasnya hasil pengamatan akibat pengaruh kondisi hormonal yang berfluktuasi pada tikus kelamin betina (Muhtadi et al., 2014).

Uji aktivitas analgesik ekstrak etanol daun C. amblycarpa dilakukan dengan metode hot plate yaitu dilakukan pengamatan waktu respon hewan uji terhadap stimulus panas dari hot plate setelah 30 menit pemberian CMC-Na $1 \%$ sebagai kontrol negatif, suspensi natrium diklofenak sebagai kontrol positif dan suspensi ekstrak etanol daun $C$. amblycarpa dengan variasi dosis $100 \mathrm{mg} / \mathrm{kgBB}$, $300 \mathrm{mg} / \mathrm{kgBB}$, dan $500 \mathrm{mg} / \mathrm{kgBB}$ sebanyak $0,5 \mathrm{~mL}$ secara peroral pada masing masing kelompok hewan uji yang dibagi dengan menggunakan teknik stratified random sampling (pengambilan acak terstratifikasi). Efektivitas analgesik dapat diketahui dengan membandingkan waktu respon hewan uji terhadap stimulasi panas antara kelompok kontrol negatif, kelompok kontrol positif, dan kelompok yang diberikan ekstrak dengan variasi dosis $100 \mathrm{mg} / \mathrm{kgBB}, 300 \mathrm{mg} / \mathrm{kgBB}$, dan $500 \mathrm{mg} / \mathrm{kgBB}$ (Patel et al., 2016).

Metode hot plate dilakukan pada suhu $70^{\circ} \mathrm{C}$ dimana panas yang ditimbulkan oleh hot plate akan direspon oleh reseptor nyeri (nosiseptor) di dalam kulit. Pengamatan respon hewan uji terhadap stimulasi panas dilakukan setiap 30 menit selama 3 jam dimana pengamatan selama 3 jam ini didasarkan pada waktu paruh Natrium Diklofenak yaitu 1-3 jam (Altaher et al., 2006). Kadar puncak ekstrak etanol daun $C$. amblycarpa dan natrium diklofenak tercapai pada menit ke-120 dimana hal ini dapat dilihat dari nilai rata-rata aktivitas analgesik keempat kelompok lainnya yang mencapai puncaknya pada menit ke-120. Di antara ketiga kelompok uji, kelompok uji dosis 100 $\mathrm{mg} / \mathrm{kgBB}$ memiliki nilai rata-rata aktivitas analgesik yang paling rendah dibandingkan dengan kelompok uji dosis $300 \mathrm{mg} / \mathrm{kgBB}$ dan $500 \mathrm{mg} / \mathrm{kgBB}$ (lihat gambar 1).

Kelompok uji dosis $500 \mathrm{mg} / \mathrm{kgBB}$ memiliki nilai rata-rata aktivitas aktivitas paling tinggi dibandingkan dengan kelompok uji dosis $300 \mathrm{mg} / \mathrm{kgBB}$ dan $100 \mathrm{mg} / \mathrm{kgBB}$. Pada menit ke-150 dan menit ke-180 terdapat penurunan rata-rata aktivitas analgesik ekstrak etanol daun C. amblycarpa pada variasi dosis $100 \mathrm{mg} / \mathrm{kggBB}, 300 \mathrm{mg} / \mathrm{kgBB}$, dan $500 \mathrm{mg} / \mathrm{kgBB}$ serta penurunan rata-rata aktivitas analgesik natrium diklofenak sebagai kontrol positif. Dilihat dari waktu paruh natrium diklofenak sebagai kontrol positif selama 1-3 jam, dapat dikatakan bahwa penurunan aktivitas analgesik pada menit ke150 dan menit ke-180 disebabkan oleh proses metabolisme obat yang terjadi dalam tubuh mencit dimana metabolisme obat merupakan proses perubahan bentuk senyawa obat ke dalam bentuk inaktifnya. (Sunarsih et al., 2011).

Persentase aktivitas masing-masing hewan uji kemudian dianalisis secara statistik dengan menggunakan SPSS versi 20. Uji statistik dilakukan untuk mengetahui aktivitas analgesik dari kelompok uji pemberian dosis ekstrak berbagai konsentrasi yang dibandingkan dengan kelompok kontrol 
DOI: https://doi.org/10.24843/JFU.2019.v08.i01.p06

pISSN: 2301-7716; eISSN: 2622-4607

Jurnal Farmasi Udayana, Vol 8, No 1, Tahun 2019, 36-43

negatif dan positif serta untuk mengetahui aktivitas analgesik kelompok kontrol negatif yang dibandingkan dengan kelompok kontrol normal, serta hasil uji Levene dapat disimpulkan bahwa sebaran data tidak homogen. Oleh karena itu, data dianalisis menggunakan analisis non-parametrik, yakni menggunakan uji Kruskall-Wallis untuk mengetahui adanya perbedaan bermakna, dilanjutkan dengan uji Mann-Whitney U untuk melihat perbedaan antara tiap kelompok perlakuan (Besral, 2010).

Hasil uji Post-Hoc Mann-Whitney U antara kelompok kontrol normal dan kelompok kontrol negatif menunjukkan tidak adanya perbedaan berrmakna ( $>>0,05)$ sehingga dapat disimpulkan bahwa tidak adanya aktivitas analgesik pada kelompok kontrol negatif yang diberi perlakuan pemberian CMC-Na 1\% secara peroral. Hasil uji Post-Hoc Mann-Whitney U antara kelompok kontrol negatif dan kelompok uji dengan pemberian suspensi ekstrak etanol daun C. amblycarpa variasi dosis 100 $\mathrm{mg} / \mathrm{kgBB}, 300 \mathrm{mg} / \mathrm{kgBB}$, dan $500 \mathrm{mg} / \mathrm{kgBB}$ menunjukkan adanya perbedaan bermakna.

Perbandingan kelompok uji dengan pemberian ekstrak dosis $500 \mathrm{mg} / \mathrm{kgBB}$ dan kontrol positif menunjukkan tidak adanya perbedaan bermakna sehingga aktivitas analgesik ekstrak etanol daun $C$. amblycarpa $500 \mathrm{mg} / \mathrm{kgBB}$ hampir mirip dengan aktivitas analgesik suspensi natrium diklofenak dosis $6,5 \mathrm{mg} / \mathrm{kgBB}$. Dari hasil uji Post-Hoc MannWhitney $\mathrm{U}$ antara ketiga kelompok yang diberikan suspensi ekstrak variasi dosis $100 \mathrm{mg} / \mathrm{kgBB}, \quad 300 \mathrm{mg} / \mathrm{kgBB}$, dan 500 $\mathrm{mg} / \mathrm{gBB}$ menunjukkan adanya perbedaan bermakna $(p<0,05)$ sehingga dapat dikatakan bahwa aktivitas yang diberikan oleh ekstrak berbeda sesuai dengan perbedaan dosis yang diberikan kepada hewan uji.

Senyawa yang diduga memberikan aktivitas analgesik pada daun C. amblycarpa adalah flavonoid dan tanin. Flavonoid merupakan senyawa polifenol utama yang normal. Hasil uji Shapiro-Wilk dapat disimpulkan bahwa data tidak terdistribusi

ditemukan pada tumbuhan, dan pada umumnya tanaman yang berasal dari genus Citrus mengandung senyawa flavonoid (Adrianto et al., 2014).

\section{KESIMPULAN}

Hasil yang diperoleh dari penelitian ini membuktikan bahwa pemberian ekstrak etanol daun jeruk limau (C. amblycarpa) pada dosis $100 \mathrm{mg} / \mathrm{kgBB}, 300 \mathrm{mg} / \mathrm{kgBB}$, dan 500 $\mathrm{mg} / \mathrm{kgBB}$ memiliki aktivitas analgesik pada mencit galur Balb/c jantan terhadap stimulasi nyeri melalui metode Hot Plate.

\section{UCAPAN TERIMAKASIH}

Terimakasih kepada Tuhan Yang Maha Esa atas berkat rahmat beliau sehingga penulis dapat menyelesaikan penelitian ini, serta semua pihak yang membantu pelaksanaan penelitian ini.

\section{DAFTAR PUSTAKA}

Adrianto, H., S. Yotopranoto, Hamidah. 2014. Efektivitas Ekstrak Daun Jeruk Purut (Citrus bystrix), Jeruk Limau (Citrus amblycarpa), dan Jeruk Bali (Citrus maxima) terhadap Larva Aedes aegypti. Aspirator. Vol. 6(1): 1-6.

Anggoro, F.N. 2014. Penatalaksanaan Fisioterapi Pada Neuropati Peroneal Di RS Pku Muhammadiyah Yogyakarta. Naskah Publikasi. Surakarta: Universitas Muhammadiyah Surakarta.

Arrington, L. R. 1972. Introductory Laboratory Animal Science, the Breeding, Care and Management of Experimental Animal. Denville: The Interstate Printers and Publisers, Inc. 
DOI: https://doi.org/10.24843/JFU.2019.v08.i01.p06 pISSN: 2301-7716; eISSN: 2622-4607

Jurnal Farmasi Udayana, Vol 8, No 1, Tahun 2019, 36-43

Besral. 2010. Pengolahan dan Analisa Data-1 Menggunakan Program SPSS. Jakarta: Departemen Biostatistika Fakultas Chaidir, L., K. Yuliani, dan B. F. T. Qurrohman. 2016. Eksplorasi dan Karakterisasi Tanaman Genjer (Limnocharis flava (L) Buch) di Kabupaten Pangandaran Berdasarkan Karakter Morfologi dan Agronomi. Jurnal Agro. Vol. 3(2): 53-66

Kumar, S. P. dan S. Svaha. 2011. Mechanismbased Classification of Pain for Physical Therapy Management in Palliative care: A Clinical Commentary. Indian Journal Palliative Care. 17(1): 80-86.

Lukman, G. dan E. Harjanto. 2007. Tata Laksana Farmakologis Nyeri Kanker. Indonesian Journal of Cancer. Vol. 3. Hal: 12-123.

Miller, J. L., J. Shick, E. D. Millikan. 2002. AHFS Drug Information. USA: American Society of Health-System Pharmacists.

Muhtadi, A. Suhendi, W. Nurcahyanti, dan E.M. Sutrisna. 2014. Uji Praklinik Antihiperurisemia Secara In Vivo Pada Mencit Putih Jantan Galur Balb-C Dari Ekstrak Daun Salam (Syzigium polyanthum Walp) Dan Daun Belimbing Wuluh (Averrhoa bilimbi L.). Biomedika. 6(1): 17-23.

Patel, P. K., J. Sahu, dan S. S. Chandel. 2016. A Detailed Review on Nociceptive Models for the Screening of Analgesic Activity in Experimental Animals.
Kesehatan Masyarakat Universitas Indonesia.

International Journal of Neurologic Physical Therapy. Vol. 2(6): 44-50.

Putra, I. G. S. 1999. Taru Pramana Khasiat Tanam-tanaman untuk Obat Tradisional. Denpasar: PT. Upada Sastra.

Sampurno et al., 2000. Parameter Standar Umum Ekstrak Tumbuhan Obat. Jakarta: Direktorat Jenderal Pengawasan Obat dan Makanan.

Sunarsih, E. S., D. H. S. Palupi, dan I. Hapsari, 2011. Pengaruh Praperlakuan Jus Kubis Bunga (Brassia oleraea L. var. botrytis L.) Terhadap Aktivitas Diklofenak Dalam Terapi Inflamasi. Majalah Obat Tradisional. Vol. 16(1): 7-13.

Shivananda, A.,D.R. Muralidhara, and K.N. Jayaveera. 2013. Analgesic and AntiInflammatory Activities of Citrus Maxima (J.Burm) Merr in Animal Models. Research Journal of Pharmaceutical, Biological and Chemical Sciences. 4(2): 1800-1810.

Vabeiryureilai, M., K. Lalrinzuali, dan G. C. Jagetia. 2015. Determination of AntiInflammatory and Analgesic Activities of a Citrus Bioflavonoid, Hesperidinin Mice. Immunochem Immunophatol. 1(2): 1-7.

WHO. 2012. WHO Guidelines on Pharmacological Treatment of Persisting Pain in Children with 
Cahyaningsih dkk.

DOI: https://doi.org/10.24843/JFU.2019.v08.i01.p06 pISSN: 2301-7716; eISSN: 2622-4607

Jurnal Farmasi Udayana, Vol 8, No 1, Tahun 2019, 36-43

Medical Illness (Tersedia pada

9789245820_Guidelines.pdf diakses

whqlibdoc.who.int/publications/2012/

pada tanggal 12 Januari 2018.

